\title{
A study on the implementation frequency of classroom management strategies by preschool teachers and how useful teachers find them*
}

\author{
Emel Durmaz, Ankara University, Turkey, drmzemel@gmail.com ORCID: 0000-0003-3152-626X \\ Fatma Çağlayan Dinçer, Hasan Kalyoncu University, Turkey, caglayan.dincer@hku.edu.tr \\ ORCID: 0000-0001-5468-9155
}

Kaan Zülfikar Deniz, Ankara University, Turkey, zlfkrdnz@yahoo.com ORCID: 0000-0003-0920-538X

\begin{abstract}
In this study, it is aimed to determine the classroom management strategies used by preschool teachers and to detect how useful they find these strategies. The screening model, which is among the quantitative research methods, was used in the study. The study group constitutes of 72 pre-school teachers, who work private and state kindergartens in Ankara and who take part in TUBITAK Project entitled the "Incredible Years (The Incredible Years-IY) Teacher Classroom Management Adaptation Program of Classroom: Turkey Sample". Teacher Classroom Management Strategies Questionnaire and the Personal Information Form were used as data collection tools in this study. In this study, only the data on the Specific Teaching Techniques Scale of the questionnaire were evaluated. Descriptive statistics and paired samples t-test were used to evaluate the data. As a result of the study, it was found that teachers used both developing and compulsive dimensions as classroom management strategies. However, teachers reported that although the developing dimension of classroom management strategies was more beneficial than the compulsive dimension, they did not frequently use strategies for the developing dimension. As a result, it has been determined that preschool teachers use compulsive classroom management strategies more frequently although they do not find it useful.
\end{abstract}

Keywords: Pre-school teachers, classroom management, classroom management strategies

Received: 17.08 .2019

Accepted: 19.05 .2020

Published: 15.09 .2020

\section{INTRODUCTION}

Manning and Bucher (2013) discusses classroom management as the strategies and techniques used to achieve desired behavior in children by implementing the planned activities in a certain order for the realization of the training process. Weber (2003) emphasizes that classroom management consists of many dimensions and states that the most important dimension among them is motivation. Therefore, it was emphasized that a classroom environment in which children will be actively involved in the learning process can be created.

It is stated that classroom management consist of 4 basic components: physical environment, learning, rules and discipline (Hue and Li, 2008). Jones (1996) discusses the components of classroom management in more detail. First of all, he emphasizes that teachers should meet the academic and psychological needs of children by mastering current studies. He further states that appropriate learning environments should be created for this. Then, he emphasizes that teacher - student interaction and peer communication should be improved and supported. In addition to these, he discussed the importance of using appropriate and various behavioral methods when dealing with behavioral problems. It can be said that teachers can ensure desired behavior acquisition, which is the main purpose in education, by using classroom management strategies effectively (Berliner, 1984; Jones and Jones, 1998; Kunter, Baumert and Köller, 2007; Marzano and Marzano, 2003).

It was stated that teachers can realize an effective classroom management by paying special attention to the classroom management strategies for classroom layout, curriculum, methods and techniques used in education, setting rules, communicating effectively, time management, and characteristics and attitudes of children and teachers (Emmer and Stough, 2001). As a result of using the classroom management strategies effectively, it can be ensured that the students participate actively in the teaching process and, so, the teaching can be

\footnotetext{
* This article is written within the scope of $113 \mathrm{~K} 713$ numbered TUBITAK SOBAG project called "The Incredible Years Adapting The Teacher Classroom Management Program to The Classroom: Turkey Sample”. Presented as an oral presentation at the 9th International Educational Research Congress held in Ordu on 11-14 May 2017.
} 
achieved in line with the determined objectives (Jones and Jones, 1998; Marzano and Marzano, 2003; Marzano, Marzano and Pickering, 2003). In addition to taking individual differences into consideration, effective classroom management can be ensured with effective communication, and problem behaviors can be prevented before they emerge (Delong and Winter, 1998; Emmer and Stough, 2001; Wang, Haertel and Walberg, 1994). Sometimes, despite all the precautions taken, problem behaviors may exist in the classroom. In order to minimize this, teachers should be able to use classroom management strategies effectively (Delong and Winter, 1998). According to Ben (2006), who supports this, a successful teacher should use classroom management strategies effectively.

Jones and Jones (1998) states that active participation of students in the education process can be ensured and emphasizes that the needs of students should be known well in order use classroom management strategies. According to Brophy (1983), and Emmer and Stough (2001), the academic success of children can be increased as well as intervening the undesired behaviors by collaborating with them through the classroom management strategies. In this regard, it can be said that the classroom management strategies used by teachers effectively have a significant effect on the quality of education and training.

As in other educational levels, classroom management in preschool education is very important in terms of the interaction between children and teachers and supporting children's behavior in the classroom. As well as establishing a preventive classroom environment, a special attention should be paid for ensuring the active participation of children in the learning process by establishing positive relationships with them. In addition to this, children and teachers should collaborate during the activities, and priority should be given to letting them confront the consequences of their behaviors when ensuring the acquisition of desired behaviors (COMP, 2017).

In their teaching pyramid, Webster-Stratton, Reinke, Herman and Newcomer (2011) included the skills and strategies used by teachers for classroom managements, and their positive effect on children. In the first layer of this pyramid, the strategies expected to be implemented by teachers for improving the problem solving, cooperation and self-confidence skills of children were determined as empathy, attention getting, playing, problem solving, listening and speaking. In the second layer, it is aimed to support the development of motivation, social and academic skills by applying praising and stimulating, and reinforcing strategies. These first two layers are seen as the basis of teaching pyramid and it is stated that teachers should absolutely use these strategies for classroom management. In the third layer, the acquisition of taking responsibility, predicting the consequences of their behaviors and complying with the rules skills is ensured after establishing the rules and class order properly. In the fourth layer, it is aimed to decrease the negative behaviors observed in children by using non-verbal clues, positive instructions and redirections. In the fifth and last layer, reminding the desired behaviors and the situations that the child will encounter as a consequence of decreasing the aggressive behaviors is considered as an effective strategy. It was emphasized that techniques such as time-out, meeting with the family, revocation of privileges given to the child and giving responsibility when implementing the above-mentioned strategies.

Hamre and Pianta (2007) states that classroom management is one of the most frequently studied subjects. In addition to this, in another study, it was determined that teachers frequently used reward-punishment system, verbal warning and praising (Akgün, Yarar and Dinçer, 2011; Drang, 2011; Sadık and Dikici Sığırtmaç, 2016). In a study conducted by Hutchings et al. (2007), it was concluded that the instructions given by the teachers with classroom management skills were clearer and they provided time for children before warning them. In another study, it was determined that the strategies for ensuring emotional support decreased problem behaviors and they ensured children establish healthy relations with both adults and their peers (Buyse, Verschueren, Doumen, Van Damme and Maes, 2008). It was stated that teachers especially tried to prevent conflicts and disputes before they emerge (Blunk, Russell and Armga, 2017) and recognition strategy had a great importance in classroom management. It was determined that the effectiveness of other strategies increased through the recognition strategy (Reinke, Lewis Palmer and Merrell, 2008). When the studies conducted are examined, it is seen that the 
teachers using effective classroom management skills actively can help children easily achieve the targeted skills in the classroom.

In a study conducted by Akar, Tantekin Erden, Tor and Şahin (2010), it was concluded that some of the teachers didn't have sufficient information about classroom management strategies and therefore could not implement these strategies. It was emphasized that they needed support in discipline, providing a multicultural education, teacher-family interaction subjects among the classroom management strategies of teachers. It was found that the subject that teachers emphasized most in classroom management was preparing an appropriate environment. In a study, Westbrook-Spaniel (2008) stated that most of the newly graduate teachers were not competent in using classroom management strategies. In another study conducted in Turkey, which is in parallel with this finding, it was concluded that newly graduate teachers didn't feel competent since the classroom management courses were not specific to the field (Öztürk, Gangal and Beşgen Ergişi, 2014).

It is seen from the related literature that there are various studies conducted on the use of classroom management strategies by the preschool teachers, their opinions on these strategies and the strategies they implement for classroom management. However, no study has been found on the relationship between these sub-titles. When the studies conducted in literature were examined, it was seen that there were no studies conducted on the consistency between the theoretical knowledge teachers obtain from the classroom management lessons and books they read, and the classroom management strategies they use. It is thought that the findings of this study will make a unique contribution to the filed on the consistency between the frequency of preschool teachers using classroom management strategies and their levels of finding these strategies useful. In line with this information, the aim of this study was to determine the frequency of preschool teachers using classroom management strategies and their levels of finding these strategies useful. Within the framework of this aim, the answers of the following research questions will be sought:

Considering the classroom management strategies;

- how often do the preschool teachers use them?

- to what extend do they find these strategies useful?

Considering the frequency of preschool teachers' use of strategies related to classroom management and their levels of finding them useful;

- is there a statistically significant difference regarding the developing sub-dimension?

- is there a statistically significant difference regarding the compulsive sub-dimension?

\section{METHOD}

\section{Research Model}

In this study, screening model, which is one of the quantitative methods, was used. With the screening model, it is ensured that the required information about the situation, event, person or object is determined as it is, it is possible to make interpretations with the data obtained from the sample group and attitudes or opinions are expressed in numerical ways (Creswell, 2014).

\section{The Study Group}

The study group consisted of 72 preschool teachers working in Ankara province of Turkey in 2015-2016 academic year. All of the participants were women. 67 teachers were working in independent preschools affiliated to Ministry of National Education (MoNE), Turkey, and 5 teachers were working in preschools affiliated to primary schools. The information about participant teachers' ages, service time in their institutions and professions, the age group they teach, the type of school they graduated and educational background were presented in Table 1 . 
Table 1. Frequency and percentage values regarding the personal information of teachers in study group

\begin{tabular}{|c|c|c|c|}
\hline & & Frequency & Percentage \\
\hline \multirow{3}{*}{ Age } & 35 and lower & 49 & 68.1 \\
\hline & $36-45$ & 16 & 22.2 \\
\hline & 46 and over & 7 & 9.7 \\
\hline \multirow{3}{*}{$\begin{array}{l}\text { Service Time in } \\
\text { Institution }\end{array}$} & 3 years and lower & 52 & 72.3 \\
\hline & 4-7 years & 15 & 20.8 \\
\hline & 7 years and over & 5 & 6.9 \\
\hline \multirow{2}{*}{$\begin{array}{l}\text { Service Time in } \\
\text { Profession }\end{array}$} & 10 years and lower & 48 & 66.7 \\
\hline & 11 years and over & 24 & 33.3 \\
\hline \multirow{3}{*}{$\begin{array}{l}\text { Age Group } \\
\text { They Teach }\end{array}$} & 36-48 Months & 17 & 23.6 \\
\hline & 49-60 Months & 36 & 50.0 \\
\hline & 61-72 Months & 19 & 26.4 \\
\hline \multirow{4}{*}{$\begin{array}{l}\text { Graduated } \\
\text { School }\end{array}$} & Faculty of Education, Preschool Teaching & 38 & 52.8 \\
\hline & Vocational Education Faculty, Preschool Teaching & 9 & 12.5 \\
\hline & Open Education Faculty, Preschool Teaching & 15 & 20.8 \\
\hline & Other & 10 & 13.9 \\
\hline \multirow{4}{*}{$\begin{array}{l}\text { Educational } \\
\text { Background }\end{array}$} & Associate Degree & 2 & 2.7 \\
\hline & Bachelor's Degree & 66 & 91.7 \\
\hline & Master's Degree & 4 & 5.6 \\
\hline & TOTAL & 72 & 100.0 \\
\hline
\end{tabular}

The ages of $68.1 \%$ of the participating teachers were 35 and lower. It was determined that most of the teachers $(66.7 \%)$ served 10 years and less in their professions and $72.3 \%$ worked in the same institution for more than 3 years. The age group of $50.0 \%$ of the participants teach was 49-60 months old children and the age group of $26.4 \%$ was $61-72$ months old children while the age group of $23.6 \%$ was $36-48$ months old children. It was determined that most of the teachers (52.8\%) graduated from the Preschool Teaching Undergraduate Programs of Faculties of Education. It was seen that the other participants graduated from Preschool Teaching Program of Open Education Faculty (20.8\%) and Preschool Teaching Program of Vocational Education Faculty $(12.5 \%)$. When the educational background of the teachers constituting the study group of this study was examined, it was determined that $91.7 \%$ of the participants had bachelor's degree.

\section{Data Collection}

The required permissions at the provincial level were obtained in order to conduct this study. Then, the study was introduced to the school principals and the willing school principals were contacted in order to determine the study group. The school principals informed the teachers in their schools and reported the names of teachers who were willing to participate in this study. The researchers requested the participants to fill in "Voluntary Participation Form" and, then, started the data collection process by making appointments with the teachers. The participating teachers were also requested to fill in a Personal Information Form in order to determine the demographic features of participants. Then, the participating teachers were requested to fill in "Teacher Classroom Management Strategies Questionnaire - Specific Teaching Techniques Scale (TCMSQ-STTS)" in order to determine the perceptions of teachers on the classroom management strategies they use. The participants stated how often they used specific teaching techniques used in classroom management and whether they found these techniques useful or not. 


\section{Data Collection Tools}

\section{Personal Information Form}

Personal Information Form was created by the researchers. This form included questions for determining the participants' ages, service time in their institutions and professions, the age group they teach, the type of school they graduated and their educational background.

\section{Teacher Classroom Management Strategies Questionnaire - Specific Teaching Techniques Scale (TCMSQ-STTS)}

In this study, Teacher Classroom Management Strategies Questionnaire developed by WebsterStratton (2012) was used. It was determined that Cronbach alpha reliability coefficients of the questionnaire were between 0.70 and 0.84 . The questionnaire consisted of 4 scales (Managing of Classroom Behavior, Specific Teaching Techniques, Working with Parents, Planning and Support) and 59 items, and each scale had different response types.

In this study, the Specific Teaching Techniques Scale on this questionnaire was used. In this scale, there were 38 items for determining how often the teachers used specific teaching techniques about classroom management in their classrooms and their opinions on how useful they found each one of these techniques in classroom management. The scale was a 5-point Likert type scale. In this study, the participants were requested to express their opinions by scoring each item as "rarely/never" (1 point), "sometimes" ( 2 points), "half the time" (3 points), "often" (4 points), and "very often" (5 points). "Use physical restraint" and "Use time out (time away to calm down) for aggressive behavior" are the examples of the items in this scale. While the teachers filling in this scale can get a maximum of 125 points and a minimum of 25 points from the Developing Techniques, they can get a maximum of 35 points and a minimum of 7 points from the Compulsive Techniques.

422 preschool teachers, who have bachelor's degree and who work in Ankara province of Turkey, was included for the adaptation of this questionnaire into Turkish. As a result of the Exploratory Factor Analysis (EFA) of Teacher Classroom Management Strategies Questionnaire Specific Teaching Techniques Scale (TCMSQ-STTS), 6 items were omitted as these items were correlated with multiple factors. Therefore, it was decided that this scale should consist of two factors (developing and compulsive) and 32 items (KMO value 0.87; the eigenvalue of the first factor 9.29, the eigenvalue of the second factor 4.01). Developing Techniques of the scale consisted of 25 items and Compulsive Techniques consisted of 7 items. It was stated that the harmony between the model obtained as a result of the Confirmatory Factor Analysis (CFA) and the data was perfect $(\chi 2=1021.82(\mathrm{df}=461 \mathrm{p}<.01)$ and $\chi 2 / \mathrm{df}=2.21)$. While the Cronbach alpha coefficient of Developing Technique was found to be 0.90 , the Cronbach alpha coefficient of Compulsive Technique was found to be 0.83 . In line with these results, it was stated that the Specific Teaching Techniques Scale sub-dimensions of this questionnaire were reliable enough (Dinçer, Deniz, Akgün and Ulubey, 2018).

\section{Data Analysis}

The data obtained in this study was analyzed using descriptive statistics and paired samples ttest within the framework of the sub-purposes. The data was analyzed by using SPSS 21 (Statistical Package Program for Social Sciences). The Teacher Classroom Management Strategies Questionnaire - Specific Teaching Techniques Scale (TCMSQ-STTS) included a 5 points Likert scale items from rarely/never (1) category to very often (5) category. As the number of participants included in this study was low $(n=72)$, it was determined that the number of participants' responses in some categories were very low. The 5 points Likert grading used was converted to a 3 points Likert grading (rarely, sometimes, and often). Thus, it was ensured that more meaningful comments were made and the distributions of points in categories were increased. In order to achieve this, the responses of the participants who replied rarely/never and sometimes were combined to get 1 point while the responses of the participants who replied often and very often were combined to get 3 points. The responses of the participants who replied half the time were taken as 2 points and the analysis was conducted accordingly. 


\section{FINDINGS}

This part included the findings related to the objectives and sub-purposes for determining the preschool teachers' frequency of using classroom management strategies and how useful they find these strategies. The descriptive statistics related to the sub-purpose of determining how often preschool teachers used classroom management strategies were presented in Table 2.

Table 2. Descriptive statistics of developing and compulsive sub-dimensions related to the frequency of use obtained from TCMSQ-STTS

\begin{tabular}{lccrrrr}
\hline $\begin{array}{l}\text { Specific Teaching } \\
\text { Techniques Scale }\end{array}$ & $\mathbf{n}$ & $\overline{\boldsymbol{x}}$ & $\begin{array}{r}\text { Item } \\
\text { mean }\end{array}$ & Min. & Max. & SD \\
\hline Developing Sub-dimension & 72 & 98.71 & 3.95 & 78.00 & 115.00 & 9.14 \\
$\begin{array}{l}\text { Compulsive Sub-dimension } \\
\text { Total }\end{array}$ & 72 & 29.68 & $\mathbf{4 . 2 4}$ & 16.00 & 35.00 & 3.57 \\
\hline
\end{tabular}

When the item averages related to the frequency of use obtained from the Teacher Classroom Management Strategies Questionnaire-Specific Teaching Techniques Scale were examined, it was seen that the average was relatively low for Developing Sub-dimension (3.95) than Compulsive Sub-dimension (4.24). The descriptive statistics related to the sub-purpose of determining how useful preschool teachers found classroom management strategies were presented in Table 3.

Table 3. Descriptive statistics of developing and compulsive sub-dimensions related to the usefulness of classroom management strategies obtained from TCMSQ-STTS

\begin{tabular}{lrrrrrr}
$\begin{array}{l}\text { Specific Teaching } \\
\text { Techniques Scale }\end{array}$ & $\mathbf{n}$ & $\overline{\boldsymbol{x}}$ & $\begin{array}{r}\text { Item } \\
\text { mean }\end{array}$ & Min. & Max. & SD \\
\hline Developing Sub-dimension & 72 & 103.91 & $\mathbf{4 . 1 6}$ & 81.44 & 124.00 & 10.17 \\
Compulsive Sub-dimension & 72 & 13.05 & 1.86 & 7.00 & 29.00 & 4.48 \\
Total & 72 & & & & & \\
\hline
\end{tabular}

When the item averages related to the usefulness of classroom management strategies obtained from the Teacher Classroom Management Strategies Questionnaire - Specific Teaching Techniques Scale (TCMSQ-STTS) were examined, it was seen that the average was relatively low for Compulsive Sub-dimension (1.86) than Developing Sub-dimension (4.16).

Considering the frequency of preschool teachers using strategies related to classroom management and their levels of finding them useful; comparisons were made in order to determine whether there was a statistically significant difference between developing and compulsive sub-dimensions or not. Paired samples t-test was used in this study as the same group had two separate measurements. The normality distribution of the data analyzed before proceeding with t-test. It was seen that skewness kurtosis coefficients were between -1 and +1 , and, therefore, $\mathrm{t}$-test was used accordingly. Considering the frequency of preschool teachers using strategies related to classroom management and their levels of finding them useful; the findings whether there was a statistically significant difference regarding Developing subdimension or not were presented in Table 4.

Table 4. T-test result regarding the frequency of use and usefulness in classroom management related to the developing sub-dimension of TCMSQ-STTS

\begin{tabular}{|c|c|c|c|c|c|c|}
\hline Developing Sub-dimension & $\mathbf{n}$ & $\bar{x}$ & SD & df & $\mathbf{t}$ & $\mathbf{p}$ \\
\hline Frequency of Use & 72 & 98.71 & 9.14 & 71 & -6.22 & $.000^{*}$ \\
\hline $\begin{array}{l}\text { Usefulness in Classroom } \\
\text { Management }\end{array}$ & 72 & 103.91 & 10.17 & & & \\
\hline
\end{tabular}

It was determined that there was a statistically significant difference between preschool teachers' frequency of use of developing strategies for classroom management and finding these strategies useful $(\mathrm{t}(71)=-6.22, \mathrm{p}<.05)$. It was seen that the average total usefulness score of preschool teachers regarding developing classroom management strategies $\left(x^{-}=103.91\right)$ was 
higher than the average total score regarding frequency of use $\left(x^{-}=98.71\right)$. Considering the frequency of preschool teachers using strategies related to classroom management and their levels of finding them useful; the findings whether there was a statistically significant difference regarding compulsive sub-dimension or not were presented in Table 5.

Table 5. T-test result regarding the frequency of use and usefulness in classroom management related to the compulsive sub-dimension of TCMSQ-STTS

\begin{tabular}{lrrrrrr}
\hline Compulsive Sub-dimension & $\mathbf{n}$ & $\overline{\boldsymbol{x}}$ & SD & df & $\mathbf{t}$ & $\mathbf{p}$ \\
\hline Frequency of Use & 72 & $\mathbf{2 9 . 6 8}$ & 3.57 & 71 & 18.66 & $.000^{*}$ \\
Usefulness in Classroom & 72 & 13.05 & 4.48 & & & \\
Management & & & & & & \\
\hline${ }^{*} \mathrm{p}<.05$ & & & & &
\end{tabular}

It was determined that there was a statistically significant difference between preschool teachers' frequency of use of compulsive strategies for classroom management and finding these strategies useful $(\mathrm{t}(71)=18.66, \mathrm{p}<.05)$. It was seen that the average total score regarding the preschool teachers' frequency of using compulsive classroom management strategies $\left(\mathrm{x}^{-}=29.68\right)$ was higher than the average total score regarding the usefulness $\left(\mathrm{x}^{-}=13.05\right)$.

\section{DISCUSSION and CONCLUSION}

This study was conducted to determine the strategies used by preschool teachers in the context of classroom management under developing and compulsive sub-dimensions and to investigate how useful preschool teachers find them considering the sub-dimensions of classroom management strategies they used. This study was conducted with 72 volunteer preschool teachers working in the independent preschools affiliated to the MoNE and preschools affiliated to primary schools in Ankara province of Turkey. The data were collected by using Teacher Classroom Management Strategies Questionnaire - Specific Teaching Techniques Scale (TCMSQSTTS). Regarding the results of this study, it was determined that preschool teachers use both developing and compulsive strategies in their classes. However, it can be said that preschool teachers used classroom management strategies without considering their compulsive and developing characteristics. It is thought that this result arises from teachers' lack of sufficient and accurate information about effective and supporting classroom management strategies. This finding is consistent with the findings of many studies in literature. Weyns et al. (2017) states that teachers use developing strategies less than compulsive strategies. For example, it was concluded that the frequency of unwanted behaviors increased when teachers demonstrated negative approaches such as criticizing these behaviors while the frequency of unwanted behaviors decreased when teachers praise desired behaviors. As a result of a study conducted by Denizel Güven and Cevher (2005), it was concluded that teachers adopted student-centered classroom management approaches as well as having sufficient classroom management skills. In the meta-analysis study conducted, it was concluded that the active participation of the child in the teaching process, intervening the unwanted behaviors, determining and teaching the rules beforehand, the provision of the appropriate physical environment in line with the needs and peer education were among the most preferred effective classroom management strategies (Simonsen, Fairbanks, Briesch, Myers and Sugia, 2008). In addition to these, Gezgin (2009) stated that teachers used the strategies they found useful in practice more frequently. Contrary to these studies, Harper (2014) concluded that teachers had to implement some strategies due to external pressures. As can be seen from both literature and results of this study, teachers use developing and compulsive strategies together for classroom management in their classes.

In this study, it was determined that the preschool teachers preferred using compulsive classroom management strategies more despite finding it useless. As compulsive classroom management strategies are behavioral, that is reactive, preschool teachers may find them facilitating in practice. However, it is thought that preschool teachers don't find these strategies useful as they know that compulsive classroom management strategies aren't effective in 
encouraging children acquire desired behaviors. In studies supporting the findings of this study, it was determined that negative classroom management strategies, developmentally inappropriate classroom management strategies for children, were used more in the learning process (Akgün et al., 2011; Harper, 2014). Denizel Güven and Cevher (2005) and Drang (2011) determined that teachers mostly used verbal stimuli as solutions against negative behaviors. In addition to these, it was seen that teachers mostly adopt an intrusive (Keleş and Yaşar, 2016) and reactive (Bulut and İflazoğlu, 2007; Jolstead et al., 2017) approach in classroom management. It was determined that preschool teachers used traditional classroom management strategies (Akar et al., 2010; Öztürk and Gangal, 2016) contrary to their opinion that they actively use contemporary classroom management strategies (Öztürk and Gangal, 2016).

Another result of this study was that teachers found it useful to use developing classroom management strategies, but they didn't use developing classroom management strategies sufficiently in their classes. Developing classroom management strategies are process-based practices as they require a precautionary perspective. In this regard, it can be said that it isn't preferred by teachers as it requires patience, foresight and planning in the process even though teachers know that it is effective in preventing the occurrence of observable unwanted behaviors. In addition to this, it is thought that teachers don't know when and how they will use developing classroom management strategies even though they know these strategies. In a study they conducted by İflazoğlu and Bulut (2005), a parallel result was observed, and it was determined that teachers and prospective teachers emphasized the importance of behavior regulation, communication and organizing teaching dimensions. In another study, it was determined that teachers thought strategies for organizing and evaluating activities and in-class communication were important (Westbrook-Spaniel, 2008). In a study conducted by Sadık and Dikici Sığırtmaç (2016), whose results aren't in parallel with this study, it was determined that teachers thought of themselves as teachers using non-interfering and interactive classroom management strategies. Blunk et al. (2017) stated that teachers could not use this strategy consistently although they set goals about social skills and appreciated children who solved their problems. It was observed that teachers set high goals in order to increase children's social competence skills and tried to prevent problems before they arose. In a study conducted by Florin (2011), it was determined that preschool teachers found themselves adequate for implementing classroom management strategies and, however, the effective classroom management strategies used by teachers had a positive effect on children's academic and social skills. It was seen that teachers needed support about discipline, multicultural education, effective teacher-family interaction (Akar et al., 2010). Based on this, it can be said that teachers need to learn and practice before they can implement developing classroom management strategies.

Based on the results obtained from this study, the following recommendations can be made:

- Teachers can improve themselves through micro teaching if the in-service trainings are practical.

- Small group trainings can be organized for preschool teachers to help them acquire the classroom management strategies expected to be used.

- It can be recommended that the content of the "Classroom Management" course in Preschool Teaching Undergraduate Programs is reorganized.

\section{REFERENCES}

Akar, H., Tantekin Erden, F., Tor, D. \& Şahin, İ. T. (2010). Öğretmenlerin sınıf yönetimi yaklaşımları ve deneyimlerinin incelenmesi. İlköğretim Online, 2(9), 792-806. Retrieved from: http://ilkogretimonline.org.tr/index.php/io/article/view/1826/1663

Akgün, E., Yarar, M. \& Dinçer, Ç. (2011). Okul öncesi öğretmenlerinin sınıf içi etkinliklerde kullandıkları sınıf yönetimi stratejilerinin incelenmesi. Pegem Eğitim ve Öğretim Dergisi, 1(3), 1-9. Retrieved 
from:https://docplayer.biz.tr/5159956-Okul-oncesi-ogretmenlerin-sinif-ici-etkinliklerdekullandiklari-sinif-yonetimi-stratejilerinin-incelenmesi.html

Ben, D. (2006). Dynamics of classroom management. (Unpublished master's thesis). ProQuest Dissertations and Theses accessed from database. (UMI No. 1440271).

Berliner, D. (1984). Research and teacher effectiveness. The Educational Resources Information Center (ERIC). Date of access 20 Temmuz 2016.

Blunk, E. M., Russell, E. M., \& Armga, C. J. (2017). The role of teachers in peer conflict: implications for teacher reflections. Teacher Development, 21(5), 597-608. doi: 10.1080/13664530.2016.1273847

Brophy, J.E. (1983). Classroom management and organization. The Elemantary School Journal, 83(4), 265282. Retrieved from: https://www.journals.uchicago.edu/doi/pdfplus/10.1086/461318

Bulut, M. S. \& İflazoğlu, A. (2007, Haziran). Ana sınıfı öğretmenleri ile öğretmen adaylarının sınıfta karşılaştıkları problem davranışlar ve bu davranışlara yönelik geliştirdikleri stratejiler: nitel bir çalışma örneği. In Neriman A. ve Belma T. (Ed.)., Avrupa Birliği Sürecinde Okul Öncesi Eğitimin Bugünü ve Geleceği Sempozyumu - With International Participation (pp.217-242). İstanbul: YaPa Yayıncilık.

Buyse, E., Verschueren, K., Doumen, S.,Van Damme, J. \& Maes, F. (2008). Classroom problem behaviour and teacher-child relationships in kindergarten: the moderating role of classroom climate. Journal of School Psychology, 46(4), 367-391. doi:10.1016/j.jsp.2007.06.009

COMP. (2017). COMP Classroom organization \& management program. Retrieved from: http://www.comp.org/GoalsPrem.html Date of access 28.07.2017.

Creswell, J. W. (2014). Research design qualitive, quantitative and mixed methods approaches. California: Sage.

Delong, M. \& Winter, D. (1998). Addressing difficulties with student-centered instruction. Primus, 8(4), 340-364. doi: 10.1080/10511979808965909

Denizel Güven, E. \& Cevher, F. N. (2005). Okul öncesi öğretmenlerinin sınıf yönetimi becerilerinin çeşitli değişkenler açısından incelenmesi. Pamukkale Üniversitesi Eğitim Fakültesi Dergisi, 18(2), 1-22. Retrieved from: https://dergipark.org.tr/pauefd/issue/11125/133051

Dinçer, Ç., Deniz, K. Z., Akgün, E. \& Ulubey, Ö. (2018). Sınıf yönetimi stratejileri ölçeğinin Türk kültürüne uyarlanması. Mersin Üniversitesi Eğitim Fakültesi Dergisi, 14(1), 355- $371 . \quad$ doi: https://doi.org/10.17860/mersinefd.361859

Drang, D. M. (2011). Preschool teachers' beliefs, knowledge and practices related to classroom management. (Doctor of thesis). ProQuest Dissertations and Theses accessed from database. (UMI No. 3495557).

Emmer, E.T. \& Stough, L. M. (2001). Classroom management: a critical part of educational psychology with implications for teacher education. Educational Psychologist, 36(2), 103-112. doi: 10.1207/S15326985EP3602_5

Florin, L. D. (2011). Kindergarten teachers' classroom management beliefs and practices and their implications on students' social an academic outcomes (Doctor of thesis). ProQuest Dissertations and Theses accessed from database. (UMI No. 3492250)

Gezgin, N. (2009). Okul öncesi eğitimi öğretmenlerinin kullandıkları sınıf yönetimi stratejileri. (Unpublished master's thesis). Uludağ Üniversitesi, Bursa.

Hamre, B., \& Pianta, R. C. (2007). Learning opportunities in preschool and early elementary classrooms. In R. C. Pianta, M. J. Cox, ve K. L. Snow (Ed.), School readiness and the transition to kindergarten in the era of accountability (pp. 49 - 84). Baltimore: Brookes.

Harper, M. D. (2014). Guidance/Classroom management stratehies of choice and teachers's preceptions of effectiveness in early childhood classrooms (Doctor of thesis). Retrieved from: www.twu.edu Date of access: 13.02 .2017$.

Hue, M. T., \& Li, W. S. (2008). Classroom management: Creating a positive learning environment (Vol. 1). Hong Kong University Press.

Hutchings, J., Daley, D., Jones, K., Martin, P., Bywater, T. \& Gwyn, R. (2007). Early results from developing and resarching the Incredible Years Teacher Classroom Management Training Programme in North West Wales. Journal of Children's Services, 2(15), 15- 26. Retrieved from: https://www.emerald.com/insight/content/doi/10.1108/17466660200700023/full/html

İflazoğlu, A. \& Bulut, S. (2005, Haziran). Ana sınıfı öğretmenleri ile öğretmen adaylarının sınıf yönetimine bakış açlları: nitel bir çalışma örneği. In G. Haktanır \& T. Güler (Ed.). I. Uluslararası Okul Öncesi Eğitimi Kongresi (pp.251-269), İstanbul. 
Jolstead, A. K., Caldarella, P., Hansen, B., Korth, B. B., Williams, L. \& Kamps, D. (2017). Implementing positive behavior support in preschools: an exploratory study of cw-fit tier I. Journal of Positive Behavior Interventions, 19(1), 48-60. doi: 10.1177/1098300716653226

Jones, V. (1996). Classroom management. In J. Sikula (Ed.), Handbook of research on teacher education (pp. 503-521). New York: Simon ve Schuster.

Jones, V. F. \& Jones, L. S. (1998). Comprehensive classroom management, creating communities of support and solving problems. USA: Allyn ve Bacon.

Keleş, O. \& Yaşar, M. (2016, Mayıs). Okul öncesi öğretmen adaylarının ve öğretmenlerinin sınıf yönetimine ilişkin tutum ve inançlarının incelenmesi. In Şakir Ç. (Ed.), 3. Uluslararası Avrasya Eğitim Araştırmaları Kongresi (pp. 376-384), Muğla Sıtkı Koçman Üniversitesi.

Kunter, M., Baumert, J. \& Köller, O. (2007). Effective classroom management and the development of subject-related interst. Learning and Instruction, 17(5), 494-509. doi: 10.1016/j.learninstruc.2007.09.002

Manning, M, L. \& Bucher, K. T. (2013). Classroom management: Models, applications, and cases. Upper Saddle River, NJ: Pearson ve Merrill Prentice Hall.

Marzano, R. J. \& Marzano, J. S. (2003). The key to classroom management. Educational Leadership, 61(1), 6-18. Retrieved

from: https://www.researchgate.net/profile/Robert Marzano/publication/283749466 The Key to Cla ssroom_Management/links/56f26c0908aed354e57293d3/The-Key-to-ClassroomManagement.pdf

Marzano, R. J., Marzano, J. S. \& Pickering, D. J. (2003). Classroom management that works: Research-based strategies for every teacher. Virginia: ASCD.

Öztürk, Y., Gangal, M. \& Beșken Ergiși, M. (2014). Okul öncesi öğretmen adaylarının eğitimlerinin sınıf yönetimi ve stratejileri üzerindeki etkisine ilişkin görüşlerinin incelenmesi. Erzincan Üniversitesi Ĕ̆itim Fakültesi Dergisi, 16(1), 224- 238. doi: http://dx.doi.org/10.17556/jef.03025

Öztürk, Y. \& Gangal, M. (2016). Okul öncesi eğitim öğretmenlerinin disiplin, sınıf yönetimi ve istenmeyen davranışlar hakkındaki inançları. Hacettepe Üniversitesi Eğitim Fakültesi Dergisi. 31(3), 593-608. Doi:10.16986/HUJE.2016015869. doi: 10.16986/HUJE.2016015869

Reinke, W. M., Lewis Palmer, T. \& Merrell, K. (2008). The classroom check-up: a classwide teacher consultation model for increasing praise and decreasing disruptive behavior. School Psychology Review, 37(3), 315-332. Retrieved from: https://www.ncbi.nlm.nih.gov/pmc/articles/PMC2603055/

Sadık, F. \& Dikici Sığırtmaç, A. (2016). Okul öncesi öğretmenlerinin sınıf yönetimi becerileri ve uygulamalarına yönelik görüşlerinin incelenmesi. Turkish Studies - International Periodical for the Languages, Literature and History of Turkish or Turkic, 14(11), 631-664. doi: http://dx.doi.org/10.7827/TurkishStudies.9630

Simonsen, B., Fairbanks, S., Briesch, A., Myers, D. \& Sugia, G. (2008). Evidence-based practices in classroom management: considerations for research to practice. Education and treatment pf children, 31(3), 351-380. Retrieved https://www.jstor.org/stable/42899983?seq=1\#metadata_info_tab_contents

Wang, M. C., Haertel, G. D. \& Walberg, H. J. (1994). Synthesis of research: What helps students learn? Educational Leadership, 51(4), 74-79. Retrieved from: http://www.ascd.org/publications/educational-leadership/dec93/vol51/num04/Synthesis-ofResearch- -What-Helps-Students-Learn\%C2\%A2.aspx

Weber, W. A. (2003). Classroom management. In J.M. Cooper (Ed.), Classroom teaching skills (pp. 222-265). New York: Houghton Mifflin Company.

Webster-Stratton, C., Reinke, W. M., Herman, K. C., \& Newcomer, L. L. (2011). The incredible years teacher classroom management training: the methods and principles that support fidelity of training delivery. School Psychology Review, 40(4), 509. Retrieved from: https://eric.ed.gov/?id=ED540771

Webster-Stratton, C. (2012). Teacher classroom management strategies questionnaire. Retrieved from: http://www.incredibleyears.com/for-researchers/measures/

Westbrook-Spaniel, C. A. (2008). How teachers learn, select and implement "Effective" classroom management strategies (Doctor of thesis). ProQuest Dissertations and Theses accessed from database. (UMI No. 3327529).

Weyns, T., Verschueren, K., Leflot, G., Onghena, P., Wouters, S. \& Colpin, H. (2017). The role of teacher behavior in children's relational aggression development: A five-wave longitudinal study. Journal of School Psychology. 67, 17-27. doi: https://doi.org/10.1016/j.jsp.2017.04.008 